\title{
Detection of roe deer, red deer, and hare meat in raw materials and processed products available in Poland
}

\author{
Lech Rak $\cdot$ Karina Knapik $\cdot$ Jacek Bania $\cdot$ \\ Jakub Sujkowski • Adam Gadzinowski
}

Received: 19 December 2013 / Revised: 24 February 2014 / Accepted: 28 February 2014 / Published online: 3 April 2014

(C) The Author(s) 2014. This article is published with open access at Springerlink.com

\begin{abstract}
To allow detection of meat from the most popular game species in Poland, we developed a PCR-based method for identification of roe deer (Capreolus capreolus), red deer (Cervus elaphus), and hare (Lepus europaeus). The designed primers were based on the noncoding, mitochondrial D-loop region. Amplicon sizes ranged from 116 to $255 \mathrm{bp}$. The primers exhibited no cross-reactivity with the DNA from common slaughter and other game species. The detection limit of the assay was established to be below $0.001 \%$ in raw red deer $(C$. elaphus) and hare (L. europaeus) meat, and below $0.01 \%$ in raw roe deer (C. capreolus) meat, whereas $<0.5 \%$ of hare and red deer meat in processed samples could be detected. The PCRbased assay was used for authentication of 17 samples of raw game meat and 32 samples of game meat-containing products available in Polish markets. Analysis of all tested raw meat and processed products revealed the presence of DNA of investigated species in concordance with producers' declarations.
\end{abstract}

Keywords Game animal meat $\cdot$ Species identification . Meat authenticity · PCR

\section{Introduction}

Adulteration of meat products may involve reduction in the meat amount or substitution of high-quality raw material

L. Rak $(\bowtie) \cdot$ K. Knapik · J. Bania · J. Sujkowski ·

A. Gadzinowski

Department of Food Hygiene and Consumer Health Protection,

Wrocław University of Environmental and Life Sciences,

Wrocław, Poland

e-mail: lech.rak@up.wroc.pl by cheaper meat of other species. Species identification in meat products is important to protect the consumer from adulteration for economical, religious, dietetic, or allergic reasons [23]. The recognition of adulteration in meat products, especially in highly processed food, is usually not feasible by the consumer. Supervision of the quality of meat products requires sophisticated laboratory methods. The choice of the diagnostic method depends on the adulteration type and applied processing technology. Some meat speciation approaches are based on the analysis of proteins by either antigenic [27], electrophoretic [21], chromatographic [3, 32] or immunochemical methods [14, 34]. However, protein denaturation during heat treatment can severely alter their antigenic and electrophoretic properties [20]. Thus, a number of currently developed detection methods of meat product adulteration are based on DNA analysis. DNA is relatively stable under common food processing conditions such as high temperatures, pressures, and chemical treatment $[8,31]$. PCR has already been used for the identification of a number of species $[1,13,15,18$, 29]. Among a variety of PCR-based techniques, the most frequently used is DNA amplification with species-specific primers $[19,30]$. Another strategy is the use of universal primers allowing annealing with conserved DNA regions of any species, coupled with restriction fragment length polymorphism [16, 35] or PCR product sequencing [9, 10, 16]. The advantage of using specific primers is reduction in expenses and the possibility of high-throughput analyses [17].

Apart from gel-based PCR methods, real-time PCR was also successfully applied for meat speciation [4, 22, 25]. Because of its non-quantitative nature, the endpoint PCR can produce similar signal from a wide range of target DNA concentrations. Therefore, its results allow only for assessment of presence or absence of the DNA of a given 
species in a product [4]. Real-time PCR can overcome these problems, since measure of signal at early phases of PCR allows for DNA quantitation in a wide dynamic range [22]. In turn, quantitative approaches, especially multiplex reactions using fluorescent probes, can be more cumbersome to design [25].

Current trends tend to eliminate fats from the diet, thus increasing interest in consuming lean meat. Game meat and its products have therefore become more in demand by consumers in many countries. The objective of this study was first to develop a PCR-based method for identification of roe deer (Capreolus capreolus), red deer (Cervus elaphus), and hare (Lepus europaeus), and then to conduct a market study using this method to test commercial products on Polish market.

\section{Materials and methods}

Samples of game animal meat were collected in game meat processing plants prior to carcass dehiding to ensure proper species recognition. Samples originated from such game animals as roe deer (C. capreolus), red deer (C. elaphus), hare (L. europaeus), quail (Coturnix coturnix), wild boar (Sus scrofa), and fallow deer (Dama dama). Samples of slaughter animal meat were taken at the slaughterhouse. Samples from slaughter animals were as follows: cow (Bos taurus), pig (Sus scrofa domestica), sheep (Ovis aries), goat (Capra hircus), rabbit (Oryctolagus cuniculus), horse (Equus caballus), chicken (Gallus gallus), turkey (Meleagris gallopavo), goose (Anser anser), duck (Anas platyrhynchos f. domestica), and ostrich (Struthio camelus). All meat samples were taken from diaphragm during postslaughter processing. Meat was packed into sterile $50-\mathrm{mL}$ vials to prevent cross-contamination. For method development, samples from 30 roe deer, 30 red deer, and 12 hare specimens were used.

Specificity of the method was tested on samples of meat of cow, pig, sheep, goat, rabbit, horse, chicken, turkey, goose, duck, ostrich, quail, wild boar, and fallow deer. These species were represented by samples from three to ten specimens each. All samples were frozen at $-18{ }^{\circ} \mathrm{C}$ until use.

All samples were taken by laboratory staff with help of veterinary inspectors from slaughter houses, or game meat processing plants to prevent errors in species recognizing.

In order to establish the assay detection limit, mixtures of raw beef containing from 0.001 to $10 \%$ of hare, roe deer, or red deer meat were prepared. Meat specimens for mixture preparation were raw, and percentages were based on wet weight. All the tests were repeated twice for each species.

The effect of heating on detection limit was tested on mixtures of beef containing $0.5-5 \%$ of hare or red deer subjected to thermal treatment, i.e., boiled in an open vessel for $40 \mathrm{~min}$ at $100{ }^{\circ} \mathrm{C}$ or autoclaved for $20 \mathrm{~min}$ at $121^{\circ} \mathrm{C}$. Aliquots of $10 \mathrm{~g}$ of these mixtures were packed in $50-\mathrm{mL}$ vials to prevent cross-contamination during thermal treatment. Screw caps of the vials were kept over water level to avoid water drainage. Meat was packed tightly to the falcon vials wall to avoid air thermal insulation effect during heating. The tests were repeated twice for each condition. Data shown represent mean values of detection limits.

A survey of the quality of commercial products was conducted on 49 samples of raw game meat and processed products purchased in local markets between 2010 and 2012. A survey of raw game meat was conducted on 17 products containing diced meat and meat pieces, since we hypothesized that diced products are more exposed to fraud by introducing small fragments of meat into the mix. The batch numbers of processed products and raw materials were checked to ensure testing of different products.

\section{DNA extraction}

A modified method described by Bania et al. [5] was used. Briefly, to a $0.5 \mathrm{~g}$ meat sample $1.5 \mathrm{~mL}$ of $0.2 \mathrm{M}$ Tris- $\mathrm{HCl}$, pH 8.0 containing $0.1 \mathrm{M}$ EDTA and $1 \%$ SDS was added. Meat samples were homogenized, and $0.6 \mathrm{mg}$ of proteinase $K$ was added twice during $24 \mathrm{~h}$ of incubation of the meat mixture at $55^{\circ} \mathrm{C}$. Samples were centrifuged for $5 \mathrm{~min}$ at $16100 \mathrm{rcf}$. Then, $0.5 \mathrm{~mL}$ of supernatant was extracted twice with equal volumes of phenol-chloroform-isoamyl alcohol (25:24:1 by volume), precipitated with $0.4 \mathrm{~mL}$ isopropyl alcohol, and washed with $1 \mathrm{~mL}$ of $70 \% \mathrm{EtOH}$. DNA pellets were dried for $1 \mathrm{~h}$ and dissolved in $50 \mu \mathrm{L}$ of $10 \mathrm{mmol} / \mathrm{L}$ Tris- $\mathrm{HCl}, \mathrm{pH} \mathrm{7.4}$, containing $0.1 \mathrm{mmol} / \mathrm{L}$ EDTA. The DNA was quantified by measuring the absorbance at $260 \mathrm{~nm}$ [33].

Design of oligonucleotide primers

Design of species-specific primers was based on Clustal $\mathrm{W}$ alignment of sequences of D-loop regions of roe deer (C. capreolus, GenBank accession number JN632610.1), red deer ( $C$. elaphus, GenBank AB245427.2), hare ( $L$. europaeus, GenBank AJ421471.1), turkey (M. gallopavo, GenBank JF275060.1), pig (S. s. domestica, GenBank FJ236997.1), chicken (G. gallus, GenBank X52392), cow (B. taurus, GenBank JN817351), sheep (O. aries, GenBank HM236183.1), rabbit (O. cuniculus, GenBank AJ001588.1), fallow deer (D. dama, GenBank AM419027), horse (E. caballus, GenBank X79547.1), goat (C. hircus, GenBank AF533441), and ostrich (S. camelus, GenBank Y12025). Alignment was performed using BioEdit software (http://www.mbio.ncsu.edu/bioedit/bioedit.html). All primers were examined for GC content, primer-dimer and 
Table 1 Oligonucleotide primers used

\begin{tabular}{|c|c|c|c|c|}
\hline Species & Primers & & $\begin{array}{l}\text { Position in complete } \\
\text { mitochondrial sequence }\end{array}$ & $\begin{array}{l}\text { Amplicon } \\
\text { size (bp) }\end{array}$ \\
\hline \multirow[t]{2}{*}{ Roe deer Capreolus capreolus } & Forward & 5'-TCCAAAAAACCAAGAACTTTAC-3' & \multirow{2}{*}{$\begin{array}{l}\text { GenBank JN632610.1 } \\
15,447-15,563\end{array}$} & \multirow[t]{2}{*}{116} \\
\hline & Reverse & 5'-CATGCTTGTGTAGTTAATTATATG-3' & & \\
\hline \multirow[t]{2}{*}{ Red deer Cervus elaphus } & Forward & 5'-CCCATTTTACATTTTACATCCACCAACC-3' & \multirow{2}{*}{$\begin{array}{l}\text { GenBank AB245427.2 } \\
15,534-15,693\end{array}$} & \multirow[t]{2}{*}{160} \\
\hline & Reverse & 5'-TATAAATAATAGAAAGTACA-3' & & \\
\hline \multirow[t]{2}{*}{ Hare Lepus europaeus } & Forward & 5'-CTGCTTTACTCTTAATAACATATC-3' & \multirow{2}{*}{$\begin{array}{l}\text { GenBank AJ421471.1 } \\
15,437-15,691\end{array}$} & \multirow[t]{2}{*}{255} \\
\hline & Reverse & 5'- CCATGTTGGTGATAGAGTTATG-3' & & \\
\hline
\end{tabular}

hairpin formation using Beacon Designer software (Premier Biosoft, USA) (Table 1).

\section{PCR}

PCR was performed in a mixture containing $1.5 \mathrm{mM}$ $\mathrm{MgCl}_{2}, 20$ nmole of each primer (Genomed, Warsaw, Poland; Table 1), $200 \mu \mathrm{M}$ of each deoxynucleotide triphosphate (Fermentas, Vilnius, Lithuania), 1 U of Taq DNA polymerase (Fermentas), and $0.5 \mu \mathrm{g}$ of DNA in a final volume of $25 \mu \mathrm{L}$.

Cycling conditions were optimized individually for each primer pair. Based on these experiments, the common PCR protocol was established, i.e., 35 cycles at $94{ }^{\circ} \mathrm{C}$ for $30 \mathrm{~s}$, $50{ }^{\circ} \mathrm{C}$ for $30 \mathrm{~s}$, and $72{ }^{\circ} \mathrm{C}$ for $30 \mathrm{~s}$. PCRs were performed separately for each primer pair on MJ Mini thermal cycler (BioRad, Warsaw, Poland). PCR products were resolved in $1.5 \%$ agarose gel containing $0.5 \mu \mathrm{g} / \mathrm{mL}$ ethidium bromide. The amplicons were visualized and documented using Gel Doc XR system (Bio-Rad).

\section{Results and discussion}

We developed a PCR-based assay for the identification of roe deer, red deer, and hare. Primers tested on the DNA isolated from roe deer, red deer, and hare were shown to produce appropriate products from the respective species (Fig. 1). The specificity of primers was tested on the DNA of common slaughter and game animal species. Meat of mentioned animal species is frequently used in meat processing plants and could be present in game meat products as contamination or adulteration. Appropriate PCR products were obtained only from the DNA of roe deer, red deer, and hare. No cross-reactivity with other abovementioned species was observed. Analysis of amplicons obtained from the mixtures of beef containing $10-0.001 \%$ of raw roe deer, hare, or red deer meat demonstrated that hare DNA was detected with the highest sensitivity, since a strong signal could be detected even at $0.001 \%$ of hare meat in beef. Signal from red deer

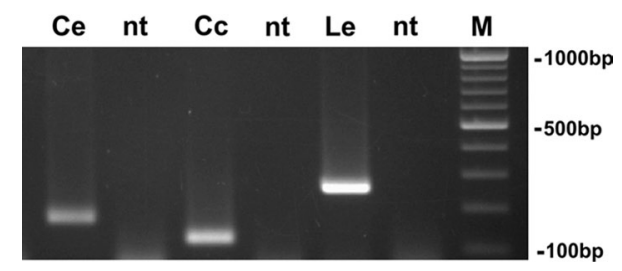

Fig. 1 PCR amplicons from the DNA of red deer (C. elaphus) (Ce), roe deer (C. capreolus) $(\mathrm{Cc})$, and hare (L. europaeus) (Le) obtained using species-specific primers. $M$ molecular weight marker (Thermo Scientific Fermentas Gene Ruler DNA Ladder Mix), nt no-template control

was detectable at $0.001 \%$. Sensitivity of PCR detection of roe deer meat was lower as the amplicons were visible at $0.01 \%$ of roe deer meat in beef (Fig. 2). The effect of thermal treatment on the detection of hare, roe deer, and red deer meats was assessed. A gradual decrease in band intensities during applied heat treatment, especially during sterilization, was observed. However, PCR performed on DNA isolated from the above mixtures at both thermal conditions revealed that the signal can be detected at $0.5 \%$ of hare and red deer meat in beef (Fig. 3). The limit of detection of our method, determined on 10 point per dilution, was shown to range from 0.01 to $0.001 \%$, depending on species. In many endpoint PCR approaches, meat content below $0.1 \%$ was usually not tested $[12,31]$. In turn, real-time PCR was shown to allow detection of meat below $0.0001 \%$ [22]. Specificity of our primers was experimentally determined using DNA from common slaughter and game species, but was also confirmed using BLAST analysis and amplicon sequencing. Results obtained using method developed here were shown to be stable over a wide range of cycling conditions illustrating its robustness. Annealing temperatures up to $60{ }^{\circ} \mathrm{C}$ and primer concentrations ranging from 5 to $20 \mathrm{n}$ mole had no impact on detection limit of the method. Also, decrease in annealing temperatures to $40{ }^{\circ} \mathrm{C}$ was shown to not affect the primers specificity.

Production of game meat in Poland reaches 14,000 metric tons a year. During 2010/2011, 160,000 heads of 
Fig. 2 Electrophoretic analysis of amplicons from DNA obtained from 0.001 to $10 \%$ mixtures of roe deer, red deer, and hare meat in beef, using species-specific primers for red deer $(\mathbf{a})$, roe deer $(\mathbf{b})$, and hare (c). $M$ molecular weight marker (Thermo Scientific Fermentas Gene Ruler DNA Ladder Mix), $0 \%$-no-template control
A $\%$ of roe deer in beef

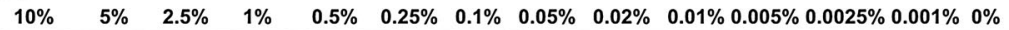

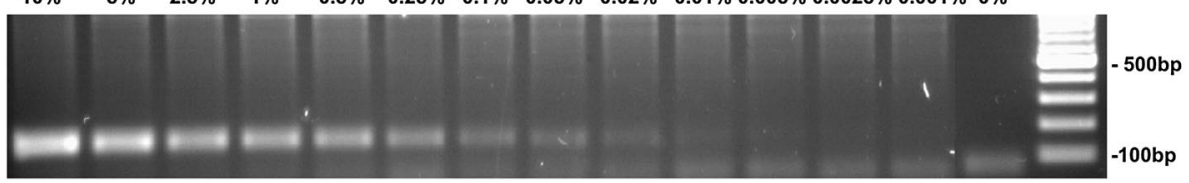

B

$\%$ of red deer in beef

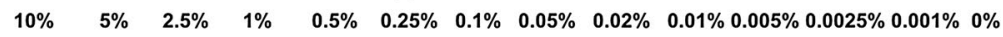

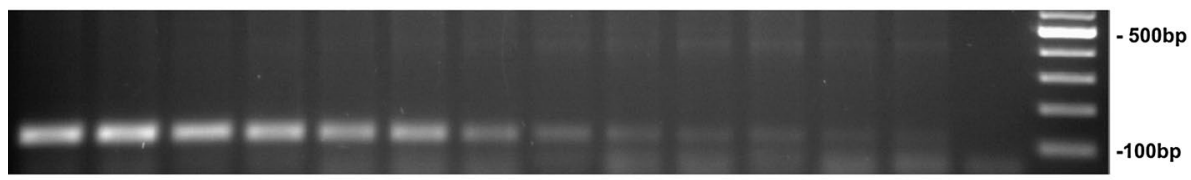

C $\%$ of hare in beef

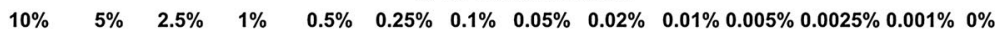

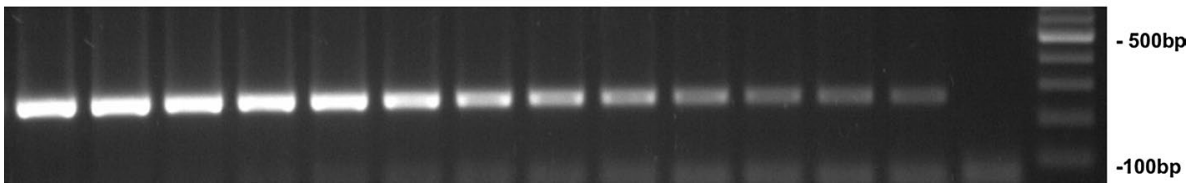

A
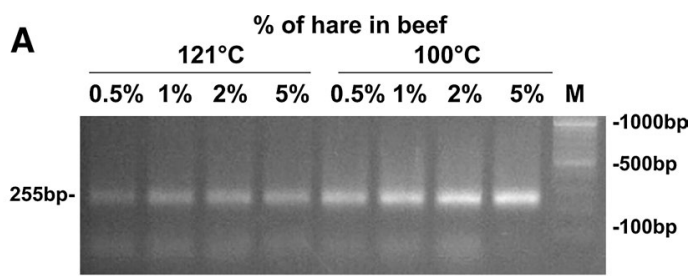

B

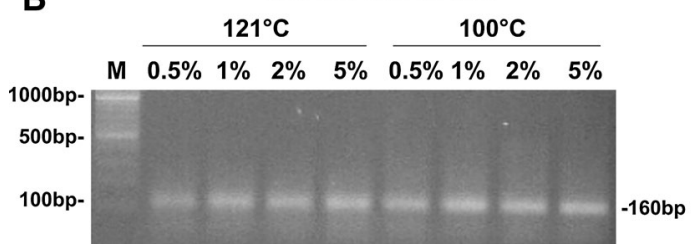

Fig. 3 Electrophoretic analysis of amplicons from DNA obtained from beef containing $0.5,1,2$ and $5 \%$ of red deer and hare. The meat mixtures were treated for $40 \mathrm{~min}$ at $100^{\circ} \mathrm{C}$ or $20 \mathrm{~min}$ at $121^{\circ} \mathrm{C}$. PCR was conducted using primers for hare (a) or red deer (b). $M$ molecular weight marker (Thermo Scientific Fermentas Gene Ruler DNA Ladder Mix)

roe deer, 54,000 of red deer, and over 17,000 hares were hunted [7]. Products including roe deer, red deer, and hare meat are most popular food containing game meat in Poland. The price of raw game meat materials is $3-8$ times higher than that of common slaughter animals. Therefore, game animal meat and its products are subject to fraudulent practices. Very little is known about the authenticity of raw game meat and products containing meat from hunted animals. Therefore, we performed a survey of authenticity of roe deer, red deer, and hare meat as well as its products like terrine and pâté available on the Polish market. Thirtytwo samples of terrine and pâté made in Poland $(n=5)$,
Germany $(n=3)$, and France $(n=24)$ were included in the survey (Table 2). We also tested 95 samples of raw game meat produced in Poland. Analysis of all tested raw meat and processed products revealed the presence of DNA of the investigated species in concordance with producer declarations.

DNA-based techniques have become very useful and widely used tools of food authentication [13, 17, 19, 23]. Surveys on authenticity of meat and its products have already been conducted in Poland also. Results of a study on species identification of beef, poultry, and pork-minced meat available on the Polish market revealed that the composition of $36 \%$ of samples differed from those declared by producers. Most of the discrepancies were detected in porcine-poultry-minced meat in which beef DNA was detected [24]. In the United States, the use of standard agar gel radial immunodiffusion test and an enzyme-linked immunosorbent assay (ELISA) has indicated minced beef adulteration. In 27 of 28 samples of tested products, high pork content was revealed [28]. In contrast, samples of beef, chicken, and pork hamburgers on the Brazilian market tested by using dot-ELISA, showed no adulteration with beef, chicken, swine, or horse meats [26]. A PCR developed to quantify pork in heated and non-processed meat, and pâtés revealed adulteration of pâtés available in Spain [6]. In Turkey, marshmallows and gum drops were analyzed using a commercial real-time PCR kit for the identification of species serving as a source of gelatin. The survey revealed the fraudulent presence of pork gelatin [11]. Assessment of meatballs on the Malaysian market also revealed fraudulent practices. Meatballs declared as made of beef, chicken, mutton, and chevon indicated the presence of pork [2]. These data indicate a wide range of fraud practices in products 
Table 2 Results of PCR analysis of processed game meat products

\begin{tabular}{|c|c|c|c|}
\hline $\begin{array}{l}\text { Animal species on the } \\
\text { product label }\end{array}$ & $\begin{array}{l}\text { Type o product and } \\
\text { number of samples }\end{array}$ & $\begin{array}{l}\text { Place of } \\
\text { production }\end{array}$ & $\begin{array}{l}\text { Confirmed DNA } \\
\text { of declared species }\end{array}$ \\
\hline Capreolus capreolus & Terrine $(n=1)$ & France & + \\
\hline Capreolus capreolus & Pâté $(n=2)$ & France & + \\
\hline Cervus elaphus & Pâté $(n=1)$ & France & + \\
\hline Cervus elaphus & Stew $(n=2)$ & France & + \\
\hline Cervus elaphus & Pâté $(n=3)$ & Germany & + \\
\hline Cervus elaphus & Pâté $(n=5)$ & Poland & + \\
\hline Lepus europaeus & Pâté $(n=10)$ & France & + \\
\hline Lepus europaeus & Terrine $(n=6)$ & France & + \\
\hline Lepus europaeus & Stew $(n=2)$ & France & + \\
\hline Cervus elaphus & Raw meat $(n=50)$ & Poland & + \\
\hline Capreolus capreolus & Raw meat $(n=45)$ & Poland & + \\
\hline
\end{tabular}

obtained from meat of common slaughter animals. There is lack of data on adulteration of game meat products on world markets. Since applied here method does not allow quantitative measure of meat content, our results demonstrate that all tested raw meat and processed products revealed the presence of DNA of investigated species in concordance with producers' declarations.

A number of one-step PCR-based methods for authentication of common slaughter animal materials in foodstuffs and feedstuffs had previously been developed. Similar methods were not available for game meat products. Primers described herein can be applied in quality control procedures in raw materials and processed products containing game species. However, there is still a need to expand the possibility of species identification to other game species.

Acknowledgments This work was supported by the Polish Ministry of Science and Information Society Technologies (Project No. N N312 427237).

\section{Conflict of interest None.}

Compliance with Ethics Requirements This article does not contain any studies with human or animal subjects.

Open Access This article is distributed under the terms of the Creative Commons Attribution License which permits any use, distribution, and reproduction in any medium, provided the original author(s) and the source are credited.

\section{References}

1. Ahmed MMM, Abdel-Rahman SM, El-Hanafy AA (2007) Application of species-specific polymerase chain reaction and cytochrome b gene for different meat species authentication. Biotechnology 6:426-430. doi:10.3923/biotech.2007.426.430

2. Ali ME, Hashim U, Mustafa S, Che Man YB, Dhahi TS, Kashif M, Uddin MK, Abd Hamid SB (2012) Analysis of pork adulteration in commercial meatballs targeting porcine-specific mitochondrial cytochrome b gene by TaqMan probe real-time polymerase chain reaction. Meat Sci 91:454-459. doi:10.1016/j.meatsci.2012.02.031

3. Ashoor SH, Monte WC, Stiles PG (1988) Liquid chromatographic identification of meats. J AOAC 71:397-403

4. Ballin NZ (2010) Authentication of meat and meat products. Meat Sci 86:577-587. doi:10.1016/j.meatsci.2010.06.001

5. Bania J, Ugorski M, Polanowski A, Adamczyk E (2001) Application of polymerase chain reaction for detection of goats' milk adulteration by milk of cow. J Dairy Res 68:333-336. doi:10.1017/S0022029901004708

6. Calvo JH, Osta R, Zaragoza P (2002) Quantitative PCR detection of pork in raw and heated ground beef and pâté. J Agric Food Chem 50:5265-5267. doi:10.1021/jf0201576

7. Central Statistical Office (2011) Statistical information and elaboration forestry. Warsaw 2011:160

8. Che Man YB, Aida AA, Raha AR, Son R (2007) Identification of pork derivatives in food products by species-specific polymerase chain reaction PCR for halal verification. Food Control 18:885889. doi:10.1016/j.foodcont.2006.05.004

9. Colombo F, Marchisio E, Pizzini A, Cantoni C (2002) Identification of the goose species Anser anser in Italian "Mortara" salami by DNA sequencing and a polymerase chain reaction with an original primer pair. Meat Sci 61:291-294. doi:10.1016/ S0309-1740(01)00195-4

10. Colombo F, Cardia A, Renon P, Cantoni C (2004) A note on the identification of Rupicapra rupicapra species by polymerase chain reaction product sequencing. Meat Sci 66:753-755. doi:10.1016/S0309-1740(03)00177-3

11. Demirhan Y, Ulca P, Senyuva HZ (2012) Detection of porcine DNA in gelatine and gelatine-containing processed food products-Halal/Kosher authentication. Meat Sci 90:686-689. doi:10.1016/j.meatsci.2011.10.014

12. Fajardo V, González I, López-Calleja I, Martín I, Rojas M, Hernández PE, García T, Martín R (2007) Identification of meats from red deer (Cervus elaphus), fallow deer (Dama dama), and roe deer (Capreolus capreolus) using polymerase chain reaction targeting specific sequences from the mitochondrial $12 \mathrm{~S}$ rRNA gene. Meat Sci 76:234-240. doi:10.1016/j.meatsci.2006.11.004

13. Fumière O, Dubois M, Baeten V, von Holst C, Berben G (2006) Effective PCR detection of animal species in highly processed animal by-products and compound feeds. Anal Bioanal Chem 385:1045-1054. doi:10.1007/s00216-006-0533-z

14. Garcia T, Martin R, Morales P, Haza AI, Anguita G, Gonzales I, Sanz B, Hernández PE (1994) Production of a horse-specific 
monoclonal antibody and detection of horse meat in raw meat mixtures by indirect ELISA. J Sci Food Agr 66:411-418. doi:10. 1002/jsfa.2740660321

15. Girish PS, Anjaneyulu ASR, Viswas KN, Santhosh FH, Bhilegaonkar KN, Agarwal RK, Kondaiah N, Nagappa K (2007) Polymerase chain reaction-restriction fragment length polymorphism of mitochondrial 12S rRNA gene: a simple method for identification of poultry meat species. Vet Res Commun 31:447-455. doi:10.1007/s11259-006-3390-5

16. Girish PS, Anjaneyulu ASR, Viswas KN, Shivakumar BM, Anand M, Patel M, Bhaskar S (2005) Meat species identification by polymerase chain reaction-restriction fragment length polymorphism PCR-RFLP of mitochondrial 12S rRNA gene. Meat Sci 70:107112. doi:10.1016/j.meatsci.2004.12.004

17. Herman BL (2001) Determination of the animal origin of raw food by species-specific PCR. J Dairy Res 68:429-436. doi: $10.1017 /$ S0022029901004940

18. Herrero B, Royo LJ, Lago FC, Vieites JM, Espiñeira M (2013) Authentication of male beef by multiplex fast real-time PCR. Food Addit Contam A 30:218-225. doi:10.1080/19440049.2012 .740164

19. Hird H, Goodier R, Hill M (2003) Rapid detection of chicken and turkey in heated meat products using the polymerase chain reaction followed by amplicon visualisation with vistra green. Meat Sci 65:1117-1123. doi:10.1016/S0309-1740(02)00341-8

20. Hofmann K (1987) Fundamental problems in identifying the animal species of muscle meat using electrophoretic methods. Fleischwirtschaft 67:820-826

21. Hsieh YH, Sheu SC, Bridgman RC (1998) Development of a monoclonal antibody specific to cooked mammalian meats. J Food Prot 61:476-481

22. Kesmen Z, Gulluce A, Sahin F, Yetim H (2009) Identification of meat species by TaqMan-based real-time PCR assay. Meat Sci 82:444-449. doi:10.1016/j.meatsci.2009.02.019

23. Kesmen Z, Sahin F, Yetim H (2007) PCR assay for the identification of animal species in cooked sausages. Meat Sci 77:649-653. doi:10.1016/j.meatsci.2007.05.018

24. Kotowicz M, Czerw M, Bania J (2005) Application of PCR for species identification in raw minced meat. Med Weter 61:1274-1276

25. López-Andreo M, Lugo L, Garrido-Pertierra A, Prietob MI, Puyet A (2005) Identification and quantitation of species in complex DNA mixtures by real-time polymerase chain reaction. Anal Biochem 339:73-82. doi:10.1016/j.ab.2004.11.045

26. Macedo-Silva A, Barbosa SF, Alkmin MG, Vaz AJ, Shimokomaki M, Tenuta-Filho A (2000) Hamburger meat identification by dot-ELISA. Meat Sci 56:189-192. doi:10.1016/ S0309-1740(00)00039-5

27. Mageau RP, Cutrufelli ME, Schwab B, Johnston RW (1984) Development of an overnight rapid bovine identification test ORBIT for field use. J AOAC 67:949-953

28. Martin DR, Chan J, Chiu JY (1998) Quantitative evaluation of pork adulteration in raw ground beef by radial immunodiffusion and enzyme-linked immunosorbent assay. J Food Prot 61:1686-1690

29. Martín I, García T, Fajardo V, López-Calleja I, Rojas M, Pavón MA, Hernández PE, González I, Martín R (2007) Detection of chicken, turkey, duck, and goose tissues in feedstuffs using species-specific polymerase chain reaction. J Anim Sci 85:452-458. doi: $10.2527 /$ jas.2006-350

30. Matsunaga T, Chikuni K, Tanabe S, Muroya S, Nakai H, Shibata K, Shibata K, Yamada J, Shinmura Y (1999) A quick and simple method for the identification of meat species and meat products by PCR assay. Meat Sci 51:143-148. doi:10.1016/ S0309-1740(98)00112-0

31. Rojas M, González I, Fajardo V, Martín I, Hernández PE, García T, Martín R (2009) Identification of raw and heat-processed meats from game bird species by polymerase chain reaction-restriction fragment length polymorphism of the mitochondrial D-loop region. Poultry Sci 88:669-679. doi:10.3382/ps.2008-00261

32. Toorop RM, Murch SJ, Ball RO (1997) Methodology and development of prediction equations for the determination of pork substitution in veal. Food Res Int 30:629-636. doi:10.1016/ S0963-9969(98)00013-1

33. Warburg O, Christian W (1942) Isolierung und kristallisation des gärungsferments enolase. Biochem Z 310:384-421

34. Whittaker RG, Spencer TL, Copland JW (1983) An enzymelinked immunosorbent assay for species identification of raw meat. J Sci Food Agr 34:1143-1148. doi:10.1002/j sfa. 2740341016

35. Wolf CH, Rentsch J, Hübner PH (1999) PCR-RFLP analysis of mitochondrial DNA: a reliable method for species identification. J Agr Food Chem 47:1350-1355. doi:10.1021/jf9808426 